\title{
Effectivity of Potassium and Fish Fertilizer on Leek Growth (Allium fistulosum L.)
}

\author{
Bina Beru Karo ${ }^{1 *}$ and Agustina E Marpaung ${ }^{1}$ \\ ${ }^{1}$ Berastagi Experimental Farm (Indonesian Vegetables Research Institute) Jl. Raya Medan-Berastagi Km. 60 Berastagi, 22156 \\ *Corresponding author: binaberukaro@pertanian.go.id
}

\section{ARTICLE HISTORY}

Received : 22 January 2020

Revised : 19 March 2020

Accepted : 10 April 2020

\section{KEYWORDS}

Allium Fistulosum L;

Potassium Fertilizer;

Fish Fertilizer;

Growth;

\begin{abstract}
Leek is one type of leaf vegetable that is commonly used for cooking vegetables or seasonings. Currently, it founded some problem in leek cultivation, including the production is low because the fertilization is not appropriate. The type and dosage of fertilizer can contribute to increasing production. This research aims to determine the dosage of potassium, and fish fertilizer is right for increased leek production. The research was conducted from January - March 2015 in the Berastagi experimental farm, with altitude \pm 1340 meters above sea level; the soil type was andisol. Experiments using a randomized block design (RBD) factorial with three replications. The first factor is the dosage of potassium fertilizer K0 $(0 \mathrm{~kg} / \mathrm{ha}), \mathrm{K} 1(100 \mathrm{~kg} / \mathrm{ha}), \mathrm{K} 2(200$ $\mathrm{kg} / \mathrm{ha}$ ), and $\mathrm{K} 3$ (300 kg/ha). The second factor is dosage fish fertilizer I0 (0 kg/ha), I1 (500 $\mathrm{kg} / \mathrm{ha}), \mathrm{I} 2(1000 \mathrm{~kg} / \mathrm{ha})$, and I3 (1500 kg/ha). The leek variety was used is local variety. The results showed that there is an interaction between the potash and fish fertilizers on leek plant height. Application potash fertilizer $\left(\mathrm{K}_{2} \mathrm{O}\right)$ dosage of $200 \mathrm{~kg} / \mathrm{ha}$ and fish fertilizer dosage of 1000 $\mathrm{kg} / \mathrm{ha}$ can increase the leek plant height $56,98 \mathrm{~cm}$. Application potash fertilizer $\left(\mathrm{K}_{2} \mathrm{O}\right)$ dosage of $200 \mathrm{~kg} /$ ha can increase the stem diameter, length of stems, length of leaves, and fresh weight per plant. Application fish fertilizer dosage of $1000 \mathrm{~kg} / \mathrm{ha}$ can increase the stem diameter, leaves length, fresh and dry weight per plant.
\end{abstract}

This is an open access article under the CC-BY-SA license.

\section{INTRODUCTION}

Leeks are often called onions Prai (Allium fistulosum L.) is one type of leaf vegetable that is commonly used for vegetables or food seasonings. The need for vegetables increases with the increase in population; therefore, it is necessary to increase the production of vegetables to meet those needs (Kumarawati, et al., 2013). Leek has an important economic value. The onion prospect is good enough to meet the needs of domestic consumers and for export demand (Yusdian, et al., 2016). Also, scallions are also often used in medicine because the compounds contained in leeks can function as antioxidants. Antioxidants in leeks can function as anti hyperlipidemia to reduce the risk of atherosclerosis and coronary heart disease (Yamamoto \& Yasuoka, 2010). Because of its use as a spice and antioxidant source, the demand for leeks in the community continues to increase.

Leek can grow optimally if the soil structure is supportive; it is available of nutrients or nutrients needed by plants (Laude \& Tambing, 2010). Leek's productivity at the farmer level is still low; one of the causes is fertilization that has not been optimal (Karo, et al., 2018). Based on data on harvested area, production, and productivity of leeks in the North Sumatra area, as listed in Table 1, shows a significant decrease in productivity. Improvements need to be made so that productivity can increase and market demand can be met. Improved productivity of leek can be done, among others, by intensive cultivation, including using planting media and providing a balanced fertilizer (Susantidiana, 2011).

Table 1. Rate of harvested area, production and productivity of leek in North Sumatra at 2010-2014

\begin{tabular}{lccccc}
\hline Description & $\mathbf{2 0 1 0}$ & $\mathbf{2 0 1 1}$ & $\mathbf{2 0 1 2}$ & $\mathbf{2 0 1 3}$ & $\mathbf{2 0 1 4}$ \\
\hline $\begin{array}{l}\text { Planting area } \\
\text { (ha) }\end{array}$ & 2.169 & 1.601 & 1.837 & 1.675 & 1.612 \\
$\begin{array}{l}\text { Production } \\
\text { (ton) }\end{array}$ & 16.957 & 9.199 & 12.366 & 12.822 & 11.534 \\
$\begin{array}{l}\text { Productivity } \\
\text { (ton/ha) }\end{array}$ & 7,82 & 5,75 & 6,73 & 7,65 & 7,15 \\
\hline
\end{tabular}

Source : BPS Sumatera Utara (2014) 
Important factors influencing the production of the leek are nutrition; availability depends on soil fertility and fertilizer application. Increasing vegetable productivity can be done by handling proper cultivation, one of which is fertilization (Karo \& Marpaung, 2016) One of the main nutrients needed for plant growth is potassium. Potassium fertilizer can increase plant resistance to water shortages and diseases and improve crop quality (Kurniawan, et al., 2017). Potassium is the most important factor in the formation and development of potato tubers (Adi, et al., 2017).

The role of the $\mathrm{K}$ element is to stimulate the assimilation translocation from the source (leaves) to the storage organ (sink), besides being involved in the process of opening and closing the stomata. Stomata will open because the guard cell absorbs water, and this water absorption occurs as a result of the presence of $\mathrm{K}$ ions. Currently, there are many results of research on fertilizing $\mathrm{K}$, the use of potassium fertilizer in the form of $\mathrm{K}_{2} \mathrm{O}$ as much as $306 \mathrm{~kg} / \mathrm{ha}$ can produce tubers as much as 31.93 tons/ha (Husadilla, et al., 2017). According to (Uke, et al., 2015) that the dosage of $\mathrm{K}$ fertilizer shows a significant difference to all plant growth parameters, a number of tubers per clump, tuber diameter, fresh tuber weight, tuber dry weight and production of onion plants.

One effort to increase crop production is through the addition of nutrients to plants through fertilization (Zakiah, et al. 2018). Application of potassium fertilizer $\left(\mathrm{K}_{2} \mathrm{SO}_{4}\right)$ has a significant effect on dried tubers per plant, fresh tubers yield per plot, and yield dried bulbs per plot on shallot plants (Gunadi, 2009). The use of potassium fertilizer in the form of $\mathrm{K}_{2} \mathrm{O}$ as much as $211 \mathrm{~kg} / \mathrm{ha}$ can produce the best growth in sweet potatoes (Apriliani, et al., 2012). The use of potassium sulfate fertilizer at a dosage of $100 \mathrm{~kg} \mathrm{~K}$ O/ha can increase the growth and yield of shallots (Karo, et al., 2016). Potassium fertilizer with a dosage of $200 \mathrm{~kg} / \mathrm{ha}$ can increase the growth and yield of carrot plants (Marpaung \& Karo, 2015).

Fertilizing efficiency can be done by administering organic material (Marpaung, et al., 2016). Organic fertilizer or natural fertilizer is fertilizer produced from the remains of plants, animals, and humans, such as green manure, compost, manure, and the results of animal and human secretions (Refliaty, et al., 2011). Organic fertilizer is very important as a buffer of physical, chemical, and biological soil properties so that it can increase fertilizer efficiency and land productivity (Supartha, et al., 2012).

Organic fertilizers contain low macronutrients but contain micronutrients in sufficient quantities that plants need for growth (Marpaung, et al., 2016). Remnant fish or wasted fish can be used as raw material for complete organic fertilizer (Zahroh, et al., 2018). In Indonesia, there are currently many organic fertilizers circulating made from raw fish that can add soil organic matter to improve soil fertility, the superiority of waste from fish. The fertilizer is that it contains complete micronutrients and macronutrients which aim to increase the growth of several types of plants (Toissuta, 2018), to maintain the state of soil organic matter, agricultural soil must always be added with a minimum of 8-9 tons/ha every year (Nazari, et al., 2012). Giving $1,200 \mathrm{~kg} / \mathrm{ha}$ of fish fertilizer produces the highest diameter of the plant, plant weight, and production (Karo, et al., 2018). This study aims to determine the appropriate dosage of potassium fertilizer and fish fertilizer to increase the production of scallions.

\section{MATERIALS AND METHODS}

The research was conducted from January to March 2015 in the Berastagi experimental farm, with altitude \pm 1340 meters above sea level, and andisol soil type. The research used factorial randomized block design (RBD) with three replications. The first factor is the dosage of Potassium fertilizer $\mathrm{K}_{0}(0 \mathrm{~kg} / \mathrm{ha}), \mathrm{K}_{1}(100 \mathrm{~kg} / \mathrm{ha}), \mathrm{K}_{2}(200$ $\mathrm{kg} / \mathrm{ha})$, and $K_{3}(300 \mathrm{~kg} / \mathrm{ha})$. The second factor is the dosage of fish fertilizer $1_{0}(0 \mathrm{~kg} / \mathrm{ha}), \mathrm{I}_{1}(500 \mathrm{~kg} / \mathrm{ha}), \mathrm{I}_{2}$ (1000 kg/ha), and $I_{3}(1500 \mathrm{~kg} / \mathrm{ha})$. The implementation procedure is planting carried out in a $1.5 \mathrm{~kg}$ volume polybag containing a mixture of soil media and manure with a ratio of 3: 1 . Potassium fertilizer and fish fertilizer carried out at the age of 30 days after planting, at which time the new roots of plants have grown, after fertilizing, then covered with soil. Plant maintenance includes weeding, irrigation, and pest/disease control. To prevent pest attacks carried out, spraying insecticides made from active Pofenofos, Chlorantranilipol $50 \mathrm{~g} / \mathrm{l}$, Imidacloprid with a concentration of $0.5-1.0 \mathrm{cc} / \mathrm{l}$ water, while to control the disease spraying fungicides Diphenoconazole $250 \mathrm{~g}$ with a concentration of $2 \mathrm{~g} / \mathrm{l}$ water. Control is done depending on the level of pest and plant disease in the field. Harvesting of leeks is done at the age of 3 months after planting.

Variables observed were: plant height (measured from ground level to highest leaf) and stem diameter (measured the largest stem diameter) observed at 10 weeks after planting (WAP). While stem length (measured from the base of the stem to the tip of the stem), leaf length (measured from leaf base to leaf tip), fresh weight (weighed after harvesting), dry weight per plant observed at harvest (dried in an oven at $70{ }^{\circ} \mathrm{C}$ for an hour and $100{ }^{\circ} \mathrm{C}$ for 3 hours, then weighed after drying). The number of plants observed was six plants per treatment unit.

The data obtained were further analyzed by the $\mathrm{F}$ test and continued with the average difference test for the HSD at the $5 \%$ level.

\section{RESULTS AND DISCUSSIONS}

\subsection{Plant Height}

Leek plant height at 10 WAP was significantly affected by the interaction between potassium fertilizer and fish fertilizer (Table 2). The use of potassium fertilizer combined with fish fertilizer for each dosage level significantly affects the height of the leek plants. The 
application of potassium fertilizer at a dosage $\left(\mathrm{K}_{2} \mathrm{O}\right)$ of $100-300 \mathrm{~kg} / \mathrm{ha}$ without fish fertilizer produced significantly higher growth of leeks compared to controls (without potassium and fish fertilizer), which ranged from 49.93-52.34 cm compared to $38.73 \mathrm{~cm}$. Whereas the application of potassium with $500 \mathrm{~kg} / \mathrm{ha}$ of fish fertilizer also gives significantly higher growth of leeks compared to without potassium, which is 52.15-53.77 cm compared to $47.79 \mathrm{~cm}$. Giving without potassium and potassium $100 \mathrm{~kg} / \mathrm{ha}$ combined with $1000 \mathrm{~kg} / \mathrm{ha}$ fish fertilizer markedly produces lower leek plants than administering potassium $200-300 \mathrm{~kg} / \mathrm{ha}$.

Table 2. Effect of interaction potassium with fish fertilizer on the high plant at 10 weeks after planting (WAP)

\begin{tabular}{|c|c|c|c|c|}
\hline \multirow{3}{*}{$\begin{array}{c}\text { The dosage of } \\
\text { Potassium } \\
\text { Fertilizer }\end{array}$} & \multicolumn{4}{|c|}{ Plant Height $(\mathrm{cm})$} \\
\hline & \multicolumn{4}{|c|}{ The dosage of Fish Fertilizer } \\
\hline & $\begin{array}{c}\mathrm{I} 0 \text { (0 } \\
\mathrm{kg} / \mathrm{ha})\end{array}$ & $\begin{array}{l}\text { I1 (500 } \\
\mathrm{kg} / \mathrm{ha})\end{array}$ & $\begin{array}{c}\mathrm{I} 2 \\
(1000 \\
\mathrm{kg} / \mathrm{ha}) \\
\end{array}$ & $\begin{array}{c}\text { I3 (1500 } \\
\mathrm{kg} / \mathrm{ha})\end{array}$ \\
\hline $\mathrm{K} 0(0 \mathrm{~kg} / \mathrm{ha})$ & $\begin{array}{c}38.73 \mathrm{c} \\
\mathrm{C}\end{array}$ & $\begin{array}{c}47.79 \mathrm{~b} \\
\mathrm{~B}\end{array}$ & $\begin{array}{c}52.75 \mathrm{a} \\
\mathrm{B}\end{array}$ & $\begin{array}{c}52.23 \mathrm{a} \\
\mathrm{BC}\end{array}$ \\
\hline $\mathrm{K} 1$ (100 kg K2 $\mathrm{O} / \mathrm{ha})$ & $\begin{array}{c}52.15 \mathrm{a} \\
\mathrm{AB}\end{array}$ & $\begin{array}{c}52.15 \mathrm{a} \\
\mathrm{A}\end{array}$ & $\begin{array}{c}52.36 \mathrm{a} \\
\mathrm{B}\end{array}$ & $\begin{array}{c}51.01 \mathrm{a} \\
\mathrm{C}\end{array}$ \\
\hline $\mathrm{K} 2(200 \mathrm{~kg} \mathrm{~K}$ O/ha) & $\begin{array}{c}49.93 \mathrm{c} \\
\mathrm{B}\end{array}$ & $\begin{array}{c}53.77 \mathrm{~b} \\
\mathrm{~A}\end{array}$ & $\begin{array}{c}56.98 \mathrm{a} \\
\mathrm{A}\end{array}$ & $\begin{array}{c}54.65 \mathrm{ab} \\
\mathrm{A}\end{array}$ \\
\hline $\mathrm{K} 3$ (300 kg K2O/ha) & $\begin{array}{c}52.34 \mathrm{~b} \\
\mathrm{~A}\end{array}$ & $\begin{array}{c}52.71 \mathrm{~b} \\
\mathrm{~A}\end{array}$ & $\begin{array}{c}55.33 \mathrm{a} \\
\mathrm{A}\end{array}$ & $\begin{array}{c}53.00 \mathrm{ab} \\
\mathrm{AB}\end{array}$ \\
\hline
\end{tabular}

$\begin{array}{cl}\mathrm{CV}(\%) & 4.06 \\ \text { Note: } & \text { Means followed by the same lowercase letter on the same row }\end{array}$ and the same uppercase letter on the same column is not significantly different by HSD test at $5 \%$ level

The interaction between potassium fertilizer and fish fertilizer on the height of leek at optimal growth age showed that the highest leek plants produced from a combination of potassium fertilizer $200 \mathrm{~kg} / \mathrm{ha}$ with fish fertilizer $1000 \mathrm{~kg} / \mathrm{ha}$. They were increasing the height of scallion plants by applying potassium fertilizer and fish fertilizer because these fertilizers can increase the availability of nutrients in the soil, and the amount of nutrient addition is very dependent on the type and dosage of fertilizer given. In addition, plants can photosynthesize perfectly, so that plant growth is perfect, this is in accordance with the opinion Napitupulu \& Winarto (2010) that K fertilizer has a very significant effect on plant height, leaf area, number of clump tubers, fresh tuber weights and dry tubers of plants shallots, (Sugiarti \& Suprihana, 2015) the treatment of fish fertilizer affects growth and garlic production.

\subsection{Diameter of Stem}

Leek stem diameter at the age of 10 WAP was not affected by the interaction between potassium fertilizer and fish fertilizer. Still, the two treatment factors giving potassium and fish fertilizer gave a real effect (Table 3 ).
Table 3. Effect of potassium and fish fertilizer on stem diameter at 10 weeks after planting (WAP)

\begin{tabular}{lrl}
\multicolumn{1}{c}{ Treatments } & Stem Diameter (cm) \\
\hline The dosage of Potassium Fertilizer & 0.74 & $\mathrm{~b}$ \\
$\mathrm{~K}_{0}(0 \mathrm{~kg} / \mathrm{ha})$ & 0.86 & $\mathrm{a}$ \\
$\mathrm{K}_{1}\left(100 \mathrm{~kg} \mathrm{~K} \mathrm{~K}_{2} \mathrm{~h} / \mathrm{ha}\right)$ & 0.87 & $\mathrm{a}$ \\
$\mathrm{K}_{2}(200 \mathrm{~kg} \mathrm{~K} \mathrm{O} / \mathrm{ha})$ & 0.80 & $\mathrm{ab}$ \\
$\mathrm{K}_{3}(300 \mathrm{~kg} \mathrm{~K} \mathrm{O} / \mathrm{ha})$ & & \\
The dosage of Fish Fertilizer & 0.75 & $\mathrm{~b}$ \\
$\mathrm{I}_{0}(0 \mathrm{~kg} / \mathrm{ha})$ & 0.82 & $\mathrm{ab}$ \\
$\mathrm{I}_{1}(500 \mathrm{~kg} / \mathrm{ha})$ & 0.87 & $\mathrm{a}$ \\
$\mathrm{I}_{2}(1000 \mathrm{~kg} / \mathrm{ha})$ & 0.84 & $\mathrm{a}$ \\
$\mathrm{I}_{3}(1500 \mathrm{~kg} / \mathrm{ha})$ & $\mathbf{9 , 0 7}$ \\
\hline CV (\%) & \multicolumn{2}{c}{} \\
\hline Note: Means followed by the same letter on the same column is not \\
significantly different by HSD test at 5\% level
\end{tabular}

Potassium fertilizer dosage treatments of 100 and $200 \mathrm{~kg} / \mathrm{ha}$ significantly resulted in a larger stem diameter compared to controls, namely 0.86 and 0.87 $\mathrm{cm}$, compared to $0.74 \mathrm{~cm}$. In contrast, the treatment of potassium fertilizer was not significantly different from one another. The provision of fish fertilizer at a dosage of $1000-1500 \mathrm{~kg} / \mathrm{ha}$ can produce significantly higher onion stem diameter compared to controls, namely 0.84 $\mathrm{cm}$ and $0.87 \mathrm{~cm}$, compared to $0.74 \mathrm{~cm}$, while there is no significant difference between treatments for fish fertilizer. Giving potassium fertilizer $\left(\mathrm{K}_{2} \mathrm{O}\right) 200 \mathrm{~kg} / \mathrm{ha}$ or fish fertilizer $1000 \mathrm{~kg} / \mathrm{ha}$, can produce a maximum stem diameter until the age of harvest. This is consistent with the dosage of $\mathrm{K}$ fertilizer on plant dry weight, leaf area, the yield of fresh tuber weight, and dried shallot (Sumarni, et al., 2012).

\subsection{Stem and Leaf Length}

Stem length and leek length did not show the effect of interaction between potassium fertilizer and fish fertilizer, but the independent treatment factor showed a real impact. Potassium administration significantly affected the length of the onion stems (Table 4). From this table, it can be seen that the administration of potassium at a dosage of $100-300 \mathrm{~kg} / \mathrm{ha}$ can increase the stem length significantly higher than without potassium. Meanwhile, the provision of fish fertilizer does not have much effect on the length of the onion stem. Leek length was significantly affected by the treatment of potassium fertilizer and fish fertilizer independently. The length of the leaves that were given potassium fertilizer was significantly longer than the control, which was 53.30-54.11 cm compared to 49.15 $\mathrm{cm}$. 
Table 4. Effect of potassium and fish fertilizer on the stem and leave length per plant

\begin{tabular}{lcc}
\hline \multirow{2}{*}{ Treatments } & \multicolumn{2}{c}{ Length (cm) } \\
\cline { 2 - 3 } & \multicolumn{1}{c}{ Stem } & Leave \\
\hline The dosage of Potassium & & \\
Fertilizer & $10.84 \mathrm{~b}$ & $49.15 \mathrm{~b}$ \\
$\mathrm{~K}_{0}(0 \mathrm{~kg} / \mathrm{ha})$ & $11.56 \mathrm{a}$ & $54.14 \mathrm{a}$ \\
$\mathrm{K}_{1}(100 \mathrm{~kg} \mathrm{~K} \mathrm{O} / \mathrm{ha})$ & $11.75 \mathrm{a}$ & $53.30 \mathrm{a}$ \\
$\mathrm{K}_{2}(200 \mathrm{~kg} \mathrm{~K} \mathrm{O} / \mathrm{ha})$ & $11.76 \mathrm{a}$ & $54.82 \mathrm{a}$ \\
$\mathrm{K}_{3}(300 \mathrm{~kg} \mathrm{~K} \mathrm{O} / \mathrm{ha})$ & & \\
The dosage of Fish Fertilizer & $11.18 \mathrm{a}$ & $50.63 \mathrm{~b}$ \\
$\mathrm{I}_{0}(0 \mathrm{~kg} / \mathrm{ha})$ & $11.43 \mathrm{a}$ & $53.12 \mathrm{ab}$ \\
$\mathrm{I}_{1}(500 \mathrm{~kg} / \mathrm{ha})$ & $11.81 \mathrm{a}$ & $53.25 \mathrm{ab}$ \\
$\mathrm{I}_{2}(1000 \mathrm{~kg} / \mathrm{ha})$ & $11.50 \mathrm{a}$ & $54.41 \mathrm{a}$ \\
$\mathrm{I}_{3}(1500 \mathrm{~kg} / \mathrm{ha})$ & & \\
\hline CV (\%) & $\mathbf{4 . 5 9}$ & $\mathbf{5 . 5 1}$ \\
\hline
\end{tabular}

Note: Means followed by the same letter on the same column is not significantly different by HSD test at $5 \%$ level

While the effect of fish fertilizer application on leaf length shows that only a dosage of $1500 \mathrm{~kg} / \mathrm{ha}$ can produce significantly longer leaf length compared to other fish fertilizer controls and treatments.

Data on Table 4 shows that the application of potassium and fish fertilizer independently can increase the growth of scallion plants, this is in accordance with the results. Potassium fertilization plays an important role in plant growth because it is indispensable in the physiological functions of plants (Farhad, et al., 2010).

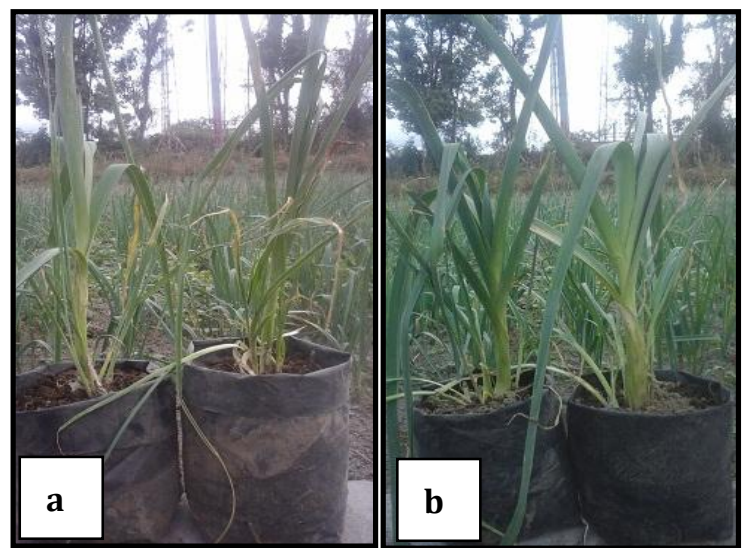

Figure 1. Control (a) and Potashium $200 \mathrm{~kg} \mathrm{~K} 2 \mathrm{O} / \mathrm{ha}+$ Fish Fertilizer $1000 \mathrm{~kg} / \mathrm{ha}$ (b)

\subsection{Fresh and Dry Weight per Plant}

The fresh and dry weight of leek is not affected by the interaction between potassium fertilizer and fish fertilizer. The application of potassium fertilizer and fish fertilizer independently on leek plants can have a significant effect on the fresh weight of plants (Table 5).

Data on Table 5 shows that potassium fertilizer with a dosage of $200 \mathrm{~kg} / \mathrm{ha}$ can produce significantly higher crop fresh weight compared to controls, which is 29.33 grams compared to 23.57 grams. In contrast, administration of potassium $100 \mathrm{~kg} / \mathrm{ha}$ and $300 \mathrm{~kg} / \mathrm{ha}$ does not show a significant effect both on control and on potassium $200 \mathrm{~kg} / \mathrm{ha}$. The application of fish fertilizer at a dosage of $500 \mathrm{~kg} / \mathrm{ha}$ and $1000 \mathrm{~kg} / \mathrm{ha}$ in leeks can significantly increase the fresh weight of plants compared to controls, namely $28.96 \mathrm{~g}$ and $29.54 \mathrm{~g}$, compared to $22.59 \mathrm{~g}$.

Table 5. Effect of potassium and fish fertilizer on fresh and dry weight per plant

\begin{tabular}{lcc}
\hline \multirow{2}{*}{ Treatments } & \multicolumn{2}{c}{ Weight per plant $(\mathrm{g})$} \\
\cline { 2 - 3 } & Fresh & Dry \\
\hline The dosage of Potassium & & \\
Fertilizer & $23.57 \mathrm{~b}$ & $2.97 \mathrm{a}$ \\
$\mathrm{K}_{0}(0 \mathrm{~kg} / \mathrm{ha})$ & $27.37 \mathrm{ab}$ & $2.90 \mathrm{a}$ \\
$\mathrm{K}_{1}\left(100 \mathrm{~kg} \mathrm{~K} \mathrm{O}_{2} / \mathrm{ha}\right)$ & $29.33 \mathrm{a}$ & $3.48 \mathrm{a}$ \\
$\mathrm{K}_{2}\left(200 \mathrm{~kg} \mathrm{~K} \mathrm{O}_{2} / \mathrm{ha}\right)$ & $27.83 \mathrm{ab}$ & $3.52 \mathrm{a}$ \\
$\mathrm{K}_{3}(300 \mathrm{~kg} \mathrm{~K} \mathrm{O} / \mathrm{ha})$ & & \\
The dosage of Fish Fertilizer & $22.59 \mathrm{~b}$ & $2.78 \mathrm{~b}$ \\
$\mathrm{I}_{0}(0 \mathrm{~kg} / \mathrm{ha})$ & $28.96 \mathrm{a}$ & $2.99 \mathrm{ab}$ \\
$\mathrm{I}_{1}(500 \mathrm{~kg} / \mathrm{ha})$ & $29.54 \mathrm{a}$ & $3.72 \mathrm{a}$ \\
$\mathrm{I}_{2}(1000 \mathrm{~kg} / \mathrm{ha})$ & $27.00 \mathrm{ab}$ & $3.38 \mathrm{ab}$ \\
$\mathrm{I}_{3}(1500 \mathrm{~kg} / \mathrm{ha})$ & & \\
\hline $\mathrm{CV}(\%)$ & 16.31 & 25.55 \\
\hline
\end{tabular}

Note: Means followed by the same letter on the same column is not significantly different by HSD test at $5 \%$ level

The dry weight of scallion plants is not much affected by potassium fertilizer, whereas fish fertilizer application shows a significant effect (Table 5). From this table, it can be seen that the giving of fish fertilizer at a dosage of $1000 \mathrm{~kg} / \mathrm{ha}$ can produce a plant dry weight of $3.72 \mathrm{~g}$, and this is significantly higher than that of control, which can only produce a plant dry weight of $2.78 \mathrm{~g}$. whereas other fish fertilizer treatments not much effect either on the control treatment or on the treatment of fish fertilizer dosages of $500 \mathrm{~kg} / \mathrm{ha}$ and $1500 \mathrm{~kg} / \mathrm{ha}$. So, potassium fertilizer and fish fertilizer can increase the production of scallions.

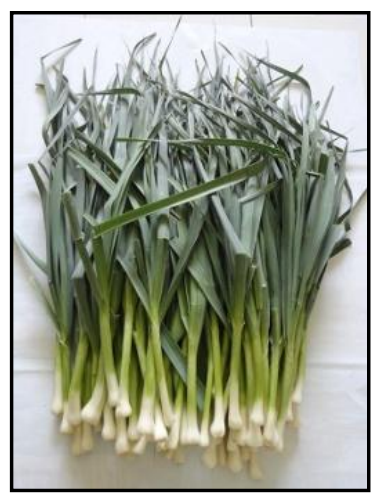

Figure 2. Leek Production 


\section{CONCLUSION}

The interaction between potassium fertilizer and fish fertilizer on the height of the leek plants. Giving a combination of potassium fertilizer $\left(\mathrm{K}_{2} \mathrm{O}\right)$ at a dosage of $200 \mathrm{~kg} / \mathrm{ha}$ and fish fertilizer at a dosage of $1000 \mathrm{~kg} / \mathrm{ha}$ can increase the height of leek plants by $56.98 \mathrm{~cm}$. Provision of $200 \mathrm{~kg} \mathrm{~K} \mathrm{~K} / \mathrm{ha}$ potassium fertilizer can increase stem diameter, stem length, and leaf length and fresh weight per plant. The application of fish fertilizer dosage of $1000 \mathrm{~kg} / \mathrm{ha}$ can increase stem diameter, leaf length, fresh weight and dry weight of the crop.

\section{REFERENCES}

Adi, I. A., Barunawati, N., \& Wardiyati, T. (2017). Pengaruh kombinasi pupuk NPK dengan jenis pupuk kandang pada pertumbuhan dan hasil kentang (Solanum tuberosum L) di dataran medium. Jurnal Produksi Tanaman, 5(4), 531-537.

Apriliani, I. N., Heddy, S., \& Suminarti, N. E. (2016). Pengaruh Kalium Pada Pertumbuhan Dan Hasil Dua Varietas Tanaman Ubi Jalar (Ipomea Batatas (L.) Lamb). Jurnal Produksi Tanaman, 4(4), 264-270.

BPS Sumatera Utara. (2014). Sumatera Utara dalam angka 2013.

Farhad, I. S. M., Islam, M. N., Hoque, S., \& Bhuiyan, M. S. I. (2010). Role of potassium and sulphur on the growth, yield and oil content of soybean (Glycine max L.). An Academic Journal of Plant Sciences, 3(2), 99-103.

Gunadi, N. (2009). Kalium sulfat dan kalium klorida sebagai sumber pupuk kalium pada tanaman bawang merah. Jurnal Hortikultura, 19(2), 174-185.

Husadilla, A., Tyasmoro, S. Y., \& Suminarti, N. E. (2018). Respon Tanaman Kentang (Solanum tuberosum L.) Pada Berbagai Dosis dan Waktu Aplikasi Pupuk Kalium. Jurnal Produksi Tanaman, 5(6), 904-910.

Uke, K. H., Barus, H., \& Madauna, I. S. Pengaruh Ukuran Umbi Dan Dosis Kalium Terhadap Pertumbuhan Dan Hasil Produksi Bawang Merah (Allium Ascalonicum L.) Varietas Lembah Palu. Agrotekbis, 3(6), 655-661.

Karo, B., Marpaung, A. E., \& Djuariah, D. (2018). Peningkatan Produksi dan Mutu Benih Kubis Bunga Melalui Pemupukan Boron dan Penggunaan Naungan Plastik Transparan (Improving Cauliflower Seed Production and Quality Through the Use of Boron Fertilizer and Plastic Transparent Shade). Jurnal Hortikultura, 27(2), 195-200.

Karo, B., \& Marpaung, A. E. (2016). Penggunaan pupuk kalium pada tanaman bawang merah (Allium cepa L.) varietas Maja di Dataran Tinggi Basah Prosiding seminar nasional BKS PTN wilayah barat bidang ilmu pertanian, Lhoksumawe, 120-125.

Karo, B., Marpaung, A. E., \& Hidayat, T. (2016). Pemanfaatan urine sapi dan kelinci sebagai pupuk cair dalam peningkatan pertumbuhan dan produksi bawang daun (Allium fistulosum L). Seminar Nasional Inovasi Teknologi Pertanian Modern Mendukung Pertanian berkelanjutan, Balai Pengkajian Teknologi Pertanian Balitbangtan Bengkulu, 323-329.
Karo, B. B., Marpaung, A. E., \& Barus, S. (2018). Respon pemanfaatan pupuk organik ikan terhadap pertumbuhan dan hasil tanaman kubis. Jurnal Agroteknosains, 2(2), 214-221.

Kumarawati, N. P. N., Supartha, I. W., \& Yuliadhi, K. A. (2013). Struktur komunitas dan serangan hama-hama penting tanaman kubis (Brassica oleracea L.). Jurnal Agroekoteknologi Tropika (Journal of Tropical Agroecotechnology), 2(4), 252-259.

Kurniawan, A., Islami, T., \& Koesriharti, K. (2017). Pengaruh Aplikasi Pupuk N Dan K Terhadap Pertumbuhan Dan Hasil Tanaman Pakcoy (Brassica Rapa Var. Chinensis) Flamingo F1. Jurnal Produksi Tanaman, 5(2), 281-289.

Laude, S., \& Tambing, Y. (2010). Pertumbuhan dan hasil bawang daun (Allium fistulosum L.) pada berbagai dosis pupuk kandang ayam. Agroland: Jurnal Ilmu-ilmu Pertanian, 17(2), 144-148.

Marpaung, A. E., \& Karo, B. (2015). Penggunaan sumber pupuk kalium dalam peningkatan hasil wortel. Jurnal Saintech, 7(4), $1-6$.

Marpaung, A., Karo, B., \& Dinata, K. (2016). Pemanfaatan pupuk organic cair (POC) dari limbah pertanian asal sumber daya alami pada budidaya sayuran bawang daun (Allium fistulosum L). In Prosiding Seminar Nasional Inovasi Teknologi Pertanian Modern Mendukung Pertanian Berkelanjutan, Bengkulu, Balai Pengkajian Teknologi Pertanian, 316-322.

Marpaung, A. E. (2018). Pemanfaatan jenis dan dosis pupuk organik cair (poc) untuk meningkatkan pertumbuhan dan hasil sayuran kubis. Jurnal Agroteknosains, 1(2), 117-123.

Marpaung, A. E., Udiarto, B. K., \& Lukman, L. (2019). Potensi Pemanfaatan Formulasi Pupuk Organik Sumber Daya Lokal untuk Budidaya Kubis (Potential Use Formulation of Fertilizer Local Natural Resources for Cabbage Plantation). Jurnal Hortikultura, 28(2), 191-200.

Napitupulu, D., \& Winarto, L. (2010). Pengaruh pemberian pupuk $\mathrm{N}$ dan $\mathrm{K}$ terhadap pertumbuhan dan produksi bawang merah. Jurnal Hortikultura, 20(1), 27-35

Nazari, Y. A., Soemarno, S., \& Agustina, L. (2012). Pengelolaan Kesuburan Tanah Pada Pertanaman Kentang Dengan Aplikasi Pupuk Organik Dan Anorganik. The Indonesian Green Technology Journal, 1(1), 7-12.

Reflianty, Tampubolon, G., \& Hendriansyah. (2011). Pengaruh kompos sisa biogas kotoran sapi terhadap perbaikan beberapa sifat fisik ultisol dan hasil kedelai (Glysine max (L) Merill). Hydrolitan, 2(3), 103-114.

Sugiarti, U., \& Suprihana, S. (2015). Pemberian limbah ikan dan pemulsaan terhadap kualitas allin sebagai anti bakteri umbi bawang putih (Allium sativum) varietas lumbu putih. Buana Sains, 15(1), 45-50.

Rosliani, R., \& Basuki, R. S. (2013). Pengaruh Varietas, Status K-Tanah, dan Dosis Pupuk Kalium terhadap Pertumbuhan, Hasil Umbi, dan Serapan Hara K Tanaman Bawang Merah. Jurnal Hortikultura, 22(3), 233-241.

Supartha, I. Y., Bijaya, G., \& Adyana, G. M. (2012). Aplikasi pupuk organik dan sistem pertanian organik padi. Jurnal Agroteknologi Tropika, 1(2), 98-106. 
Susantidiana. (2011). Peran media tanam dan dosis pupuk Urea, SP36, KCl terhadap pertumbuhan tanaman bawang daun (Allium fistulosum L.) dalam polybag. Agronobis, 3(5), 17-21.

Toissuta, B. (2018). Pengaruh konsentrasi pupuk organik cair dari limbah ikan tuna (Thunus $\mathrm{sp}$ ) terhadap pertumbuhan tanaman sawi. Jurnal Univera, 7(1), 52-60.

Uke, K. H., Barus, H., \& Madauna, I. S. Pengaruh Ukuran Umbi Dan Dosis Kalium Terhadap Pertumbuhan Dan Hasil Produksi Bawang Merah (Allium Ascalonicum L.) Varietas Lembah Palu. Agrotekbis, 3(6), 655-661.

Yamamoto, Y., \& Yasuoka, A. (2010). Welsh onion attenuates hyperlipidemia in rats fed on high-fat high-sucrose diet. Bioscience, biotechnology, and biochemistry, 74(2), 402-404.

Yusdian, Y., Antralina, M., \& Diki, A. (2016). Pertumbuhan dan hasil bawang daun (Allium fistulosum 1.) varietas linda akibat pemberian pupuk kandang ayam dan pupuk urea. Jurnal Agro, 3(1), 20-24.

Zahroh, F., Kusrinah, K., \& Setyawati, S. M. (2018). Perbandingan Variasi Konsentrasi Pupuk Organik Cair dari Limbah Ikan Terhadap Pertumbuhan Tanaman Cabai Merah (Capsicum annum L.). Al-Hayat: Journal of Biology and Applied Biology, 1(1), 50-57.

Zakiah, K., Erawan, W., \& Rahmat, M. (2018). Respon pertumbuhan dan hasil tanaman wortel (Daucus carota L.) akibat pemberian urin kelinci. Jagros: Jurnal Agroteknologi dan Sains (Journal of Agrotechnology Science), 2(2), 130-137. 